\title{
Mobil Pazarlamanın İlk Uygulaması Olan SMS Reklamlarına Yönelik Eğilimlerin Saptanması: Üniversite Öğrencileri Üzerine Bir İnceleme
}

\author{
Bahadır Burak SOLAK ${ }^{1}$ ve Zöhre AKYOL ${ }^{2}$ \\ $\ddot{O} z$
}

Hedef kitleye daha uygun maliyetle, etkili ve doğrudan ulaşmak için yeni yollar arayan reklamcilar cep telefonu kullanan insan sayısının hızla artmasıyla mobil pazarlamaya yönelmişlerdir. Bu kapsamda cep telefonları reklamcılar tarafindan yeni bir reklam mecrası olarak yoğun bir şekilde kullanılmaya başlanmıştır. Yaşanan bu gelişmeler ve değişimlerden sonra cep telefonları, önemli iletişim aracı olmasının yanı sıra en etkin dijital reklam mecralarından biri olarak görülmektedir. Genellikle reklam içerikli mesajlarla bir ürünün/hizmetin tanıtılması, indirimler ve kampanyalar gibi temel pazarlama karması öğeleri kullanılarak iletişim çalıșmaları yürütülmektedir. Sonuç olarak markalar mobil pazarlama sayesinde, giderek rekabetin arttığı pazar ortamında çağın gerekliliklerine uygun, daha az maliyetle zaman ve mekân kısıtlaması olmaksızın tüketicilere reklam mesajlarını iletebilmektedir. Yukarıda bahsedilenler doğrultusunda araştırmanın genel amacı, mobil pazarlamanın ilk ve en yaygın kullanılan uygulaması olan kısa mesaj (SMS) yöntemi ile yapılan mobil reklamlara yönelik üniversite öğrencilerinin eğilimlerinin ne yönde (olumlu/olumsuz) olduğunun ortaya çıkarılmasıdır. Bu kapsamda Ege Üniversitesi İletişim Fakültesi bünyesinde yer alan Gazetecilik, Halkla İlişkiler ve Tanıtım, Radyo Televizyon ve Sinema, Reklamcılık bölümlerinde okuyan öğrenciler araştırma evrenini oluşturmuştur. Araştırma evreni içinde örneklemi olușturan 395 öğrenciye araştırma dâhilinde belirlenen sorularla hazırlanan anket çalışması uygulanmıştır. Araştırmanın amacına uygun olarak betimsel (tanımlayıcı) ve bağıntısal araştırma modeli kullanılmıştır. Bu bağlamda anket sonucunda elde edilen veriler doğrultusunda markalar tarafindan öğrencilere gönderilen SMS reklamlarına yönelik genel eğilimin olumlu olduğu tespit edilmiştir.

Anabtar Kelimeler: Pazarlama İletişimi, Mobil Pazarlama, SMS Reklamları

Determination of Tendencies toward SMS Ads as the First Application of Mobile Marketing: A Study on University Students

\begin{abstract}
The advertisers who are looking for new ways to reach the target audience in a more cost-effective, direct and effective way, have turned to mobile marketing with the increasing number of people using mobile phones. In this context, mobile phones have been used intensively by advertisers as a new advertising medium. After these developments and changes, mobile phones are seen as one of the most effective digital advertising media as well as being an important communication tool. Communication activities are generally carried out using basic marketing mix elements such as promotion of a product / service, discounts and campaigns with advertising messages. As a result, through mobile marketing, brands are able to communicate their advertising messages to consumers in a market environment in which the competition is increasing in line with the requirements of the era and without time and space constraints at less cost. The general aim of the study is to determine the tendency of university students (mobile / negative) for mobile advertising made by text message (SMS) method, which is the first and most widely used application of mobile marketing. In this context, the students studying in the departments of Journalism, Public Relations and Publicity, Radio Television and Cinema, Advertising, which is a part of Ege University Communication Faculty, formed the research universe. 395 students in the research universe were included in the study. A descriptive (descriptive) and correlational research model was used for the purpose of the study. In this context, in line with the data obtained from the survey, the general trend towards SMS advertisements sent to students by brands was found to be positive.
\end{abstract}

Key Words: Marketing Communication, Mobile Marketing, SMS Ads

Atıf İçin / Please Cite As:

Solak, B. B. ve Akyol, Z. (2020). Mobil pazarlamanın ilk uygulaması olan SMS reklamlarına yönelik eğilimlerin saptanması: Üniversite öğrencileri üzerine bir inceleme. Manas Sosyal Araşttrmalar Dergisi, 9(2), 886-898.

Geliş Tarihi / Received Date: 28.03.2019

Kabul Tarihi / Accepted Date: 13.11.2019

\footnotetext{
${ }_{1}^{1}$ Arş. Gör. - Trabzon Üniversitesi İletişim Fakültesi, b.brksolak@trabzon.edu.tr - ORCID: 0000-0001-6670-8931

2 Arş. Gör. Dr. - Zonguldak Bülent Ecevit Üniversitesi, İletişim Fakültesi, z.resber@beun.edu.tr - ORCID: 0000-0003-3270-0258
} 


\section{Giriş}

Mobil cihazlar bireyleri dijital ve sosyal ağlara bağlayan bir araçtır. Dolayısıyla bu cihazlar onların dijital olarak her türlü iletişim sürecine dâhil olmalarına imkân tanımaktadır. İnsanlar mobil cihazlar aracilığyla nerede olduklarını bildirir, tweet atar ve durumlarını herhangi bir yerde ve zamanda güncelleyebilirler. Ayrıca markalarla ilgili değerlendirmeleri okuyabilir, fiyatları kontrol edebilir ve onlarla iletişime geçebilirler. Marka tarafindan değerlendirildiğinde ise mobil cihazlar sayesinde hedef kitleye uygun zamanda ve yerde ürün ve hizmetler hakkında bilgilendirme yapılabilir. Bir alışveriş merkezine veya süper markete girildiği zaman oradaki kampanyalarla ilgili anında bilgilendirme mesajları gelmesi buna örnek verilebilir. Bu durum mobil cihazların pazarlama amaçı kullanımını göstermektedir. Etkili mobil pazarlama bir markanın hedef kitlesine yönelik mobil cihaz kullanım özelliklerinin belirlenerek bir strateji oluşturulmasını gerektirmektedir. Mobil pazarlamanın farklı türleri söz konusudur. Bunlar; SMS (metin mesajları) reklamları, display reklamlar, uygulama içi reklamlar, QR kodlar, arama motoru ve sosyal medya reklamları olarak tanımlanabilir (Clow ve Baack, 2016, s. 231). Bu türlerden SMS reklamı hariç diğerleri için çevrimiçi özelliğe sahip akıllı mobil cihazlar gerekmektedir. Ancak SMS reklamları tüm mobil cihazlar için uygundur. Zaten bu durumdan dolayı SMS reklamları mobil pazarlamanın ilk ve en çok uygulanan türü olarak değerlendirilmektedir.

Sürekli değişen pazar ve tüketici yapısı, markaları hedef kitleye ulaşma noktasında farklı uygulamalar bulmaya yönlendirmektedir. Mobil pazarlama ve SMS reklamları bu yeni uygulamalardan birini oluşturmaktadır. SMS, bugüne kadarki en popüler mobil veri uygulaması olmasının yanı sıra uygun ve düşük maliyetli bir mobil iletişim teknolojisi olarak tanımlamaktadır (Xu, Teo ve Wang, 2003, s. 5). Her yaştan kullanıcıya hem sosyal hem de iş iletişimi ile ilgili mesaj alışverişinde bulunma olanağı sağlamaktadır. Bu bağlamda SMS bilgi ve teknoloji çağında kişilerarası iletişim için son derece önemli ve sık kullanılan bir araç olarak karşımıza çıkmaktadır (Carroll vd., 2007, s. 81). SMS’in artan bu popülaritesi pazarlama ve reklamcilık uygulamaları için yeni bir kanal ortaya çıkararak reklamların bu kanal aracıllğıyla kısa metin mesajları olarak cep telefonlarına gönderilmesini sağlamıştır (Tsang vd., 2004, s. 68). Reklam yoğunluğunun olduğu günümüzde, reklam mesajların kişiselleştirilerek tüketicilere aktarılmasını sağlayan mobil reklamcilık aracillğıyla markalar, bu yoğunluğun içinden siyrllarak tüketicilerin ilgisinin markalara yönelmesini sağlayabilmektedir. Mobil reklamcllık, reklam mesajlarının cep telefonu gibi mobil cihazlarla hedef kitleye iletilmesini ifade etmektedir. SMS mobil reklamcillkta en çok tercih edilen yöntemdir. Bu yöntem kapsamında SMS aracilığyla cep telefonlarına kısa metin tabanlı reklam mesajları iletilmektedir (Haghirian vd., 2005, s. 2).

Teknolojinin sürekli gelişmesiyle birlikte mobil cihazların kullanımı hızla artmaktadır. Bu durum markaların hedef kitleyle interaktif olarak iletişim kurmasına olanak sağlamaktadır. Özellikle geleneksel medyanın etkinliğini büyük oranda kaybetmesi, etkileşimli ve kişisel mesajların hedef kitle nezdinde daha yoğun olarak kabul görmesi mobil cihazların pazarlama ve reklam aracı olarak kullanılma firsatını ortaya çıkarmıştır. Mobil cihazların bir reklam mecrası olarak en büyük faydası her zaman tüketicilerin yanında ve kullanıma açık olmasıdır. Böylelikle markaların anlık olarak tüketicilere ulaşması mümkün olmaktadır. Mobil pazarlama kapsamında ilk ve en yaygın kullanılan uygulama SMS reklamlarıdır. SMS reklamları başlangiçta basit bir şekilde, mevcut ve potansiyel müşterilerin cep telefonlarına iletilen bir reklam mesajını temsil ederken günümüzde reklam kampanyalarında değişik yollarla ve sıklıkla kullanılan bir reklam türü olarak değerlendirilmeye başlanmıştır. Bu bağlamda günümüzde SMS reklamları; televizyon, radyo, açı hava, gazete reklamları gibi geleneksel olan ancak etkileşimli olmayan ortamlar aracilığıyla yayınlanan reklam içeriğine etkileşim kazandırmak için kullanılmaktadır. Günümüzde yaşanan tüm bu gelişmeler sonucu itibariyle markalar tarafından SMS reklamları tüketicileri ikna etmek için yoğun olarak tercih edilmektedir. Bu bağlamda çalışmada temel olarak, mobil pazarlama uygulamalarından biri olan SMS reklamlarına yönelik üniversite öğrencilerinin eğilimlerinin, olumlu mu yoksa olumsuz mu olduğu konusuna açıklık getirilmeye çalışılmıştır.

Türkiye özelinde bu konuda önceden yapılan çalışmalara bakıldığında araştırmaların daha çok genel anlamda mobil pazarlama ve genel tüketici kitlesine odaklandığı görülmüştür. Mobil pazarlamanın ilk uygulaması olan SMS reklamlarına ve üniversite öğrencilerine yönelik çalışmaya literatürde çok fazla rastlanmamıştır. Bu kapsamda bulunan sayılı örnek çalışmaların sonuçlarına bakıldığında SMS reklamlarına yönelik genel eğilimin negatif olduğu gözlemlenmiştir. Sadece Çakır ve Çiftçi (2010) tarafından yapılan çalısmada; cep telefonunu sık kullanan genç kitle olarak üniversite öğrencilerinin, işletmelerin SMS reklam ve pazarlama içerikli mesajlarına olumlu bir tutum ve davranış gösterdiği sonucuna ulaşılmıştır. Diğer taraftan İspir ve Suher'in (2009) yaptı̆̆ı çalışmaya bakıldığında genç 
tüketicilerin SMS reklamlarının alımına yönelik olumsuz tutumları olduğu görülmektedir. Bunun temel sebebinin mobil telefonların kişisel ve özel cihazlar olmalarından dolayı SMS reklamlarının rahatsız edici bulunması sonucuna varılmıştır. Usta (2009) tarafından yapılan araştırmanın sonucuna göre ise yine öğrencilerin kısa mesaj reklâmlarına karşı genel tutumları olumsuzdur. Ancak reklamlar izinli ve ödüllü olursa tutumlar olumlu olmaktadır. Ayrıca öğrenciler reklamları eğlendirici, bilgilendirici ve güvenilir bulmamaktadırlar. Aynı zamanda da sinir bozucu olduklarını düşünmektedirler. Benzer şekilde Doğaner ve Kuyucular (2017) tarafindan yapılan araştırmanın sonucuna göre de genç tüketicilerin mobil reklamcilğga karşı tutumları genellikle olumsuzdur. Faktörlere yönelik tutumların ortalamasının sonucu bağlamında mobil reklamlara yönelik tutumlar açısından en yüksek ortalamaya sahip faktörün rahatsız etme faktörü olduğu anlaşılmışır. Yani genç tüketiciler izinsiz gelen SMS reklamlarına yönelik olumsuz tutumları olduğunu belirtmiştir. Kendilerinden izin alınarak veya kendilerine bilgi verilen veya ilgi alanlarına yönelik bireyselleştirilmiş olarak yapılan SMS reklamlarınaysa daha fazla ilgi göstermektedirler. Bu bağlamda mobil reklamcilı̆ın izinli ve daha fazla kişiselleştirilmiş olarak yapılması, pazarlama açısından olumlu sonuçlar doğuracaktır sonucuna ulaşılmışır.

\section{Literatür İncelemesi}

Amerikan Pazarlama Derneği, pazarlamayı bireysel ve kurumsal ihtiyaçları/hedefleri tatmin edecek değiş/tokuş (satış ve satın alma) ortamının yaratılması için fikirlerin, ürünlerin ve hizmetlerin geliştirilmesi, fiyatlandırılması, dağıtımı ve tanıtımına (tutundurulmasına) yönelik planlama ve uygulama süreci olarak tanımlamaktadır (American Marketing Association, 2013). Bu tanıma göre, alıcılar ve satıcılar zamansal ve mekânsal olarak birbirlerinden ayrıdırlar. Günümüzde ise geleneksel pazarlama gerek teknolojik yenilikler gerekse de ekonomik dönüşümlerle birlikte yerini farklı pazarlama anlayışlarına bırakmıştır. Bunlardan biri de dijital pazarlama olarak kabul edilmektedir. Dijital pazarlama, geleneksel pazarlamanın zaman ve mekân tanımlamasını dönüştürerek kişiselleştirmenin önemini arttırmaktadır (Scharl, Dickinger ve Murphy, 2005, s. 164). Böylelikle markalar tarafindan yürütülen geleneksel pazarlama anlayışı yerini etkileşimli ve hedef kitlenin isteklerinin pazarlama uygulamalarının içerisine dâhil edildiği bir anlayışa bırakmıştır.

Dijital pazarlama genellikle doğrudan pazarlamanın bir aracı olarak kullanılmaktadır. Scharl ve diğerleri (2005, s. 165), dijital pazarlamayı, tüketiciyle doğrudan etkileşim içinde olan bunun yanı sıra tüketicinin markanın mesajına anlık tepki vermesini sağlayan ve dijital reklam mecraları yoluyla gerçekleșen pazarlama olarak tanımlamaktadır. Dijital pazarlamada önemli olan etkileşimli bir iletişimi sağlamak ve hedef kitleyi her an yakalayabilmektir. Bu noktada da dijital pazarlamanın bir alt dalı olan mobil pazarlama ya da kablosuz pazarlama ön plana çıkmaktadır. Mobil Pazarlama Derneği (MMA) mobil pazarlamayı markaların, herhangi bir mobil cihaz veya ağ üzerinden hedef kitle ile direkt bir şekilde iletişim kurmasını ve etkileşimde bulunmasını sağlayan bir dizi uygulama olarak tanımlamaktadır (Mobile Marketing Association, 2009). Bir başka tanıma göreyse mobil pazarlama, marka ve hedef kitle arasında bir mobil ortam, cihaz veya teknolojik ağ kullanılarak iletilen teklifin iki yönlü ve etkileşimli bir şekilde tanıtım sürecidir (Shankar ve Balasubramanian, 2009, s. 118). Mobil pazarlamada amaç, bir markanın ürün ya da hizmetlerini kablosuz bir ortam üzerinden hedef kitlelere tanıtmaktır. Böylelikle marka, zaman ve mekan faktörlerine takılmaksızın SMS reklamlarını büyük bir rahatlıkla hedef kitleye iletebilmektedir. Özellikle müşteriyle olan iletişimi etkin bir şekilde yönetmek için mobil cihazlar son derece önemli konuma gelmiştir. Ayrıca müşteriyle ilişkiler kurma ve geliştirmede markalara eşi görülmemiş firsatlar sunmaya başlamışıtır (Varnalı ve Toker, 2010, s. 144).

Cep telefonu kullanımının artması ve tüketici hayatında önemli bir yere gelmesi ile birlikte cep telefonlarının bir pazarlama kanalı olarak kullanımı artış göstermiştir. Mobil pazarlama detaylı kullanıcı bilgisi ve kişiselleştirme potansiyeline sahip bir yapı göstermektedir. Daha iyi hedefleme yapmak için içerik her müşteriye özel olarak uyarlanabilmektedir. Mobil telefonlar kişisel nesneler olduğundan, pazarlamacılar hedeflenen kişiyi özel olarak ele alabilir, sosyal bağlamlarını, bireysel tercihlerini, tüketicilerin zamanlamasını ve mekansal tercihlerini öğrenerek, onlara uygun mesajlar gönderebilmektedir. Mobil kanal aracılığılla yapılan reklamlar, anında etkileşim alınacak yapıdadır. Ayrıca mobil reklamlar, her zaman ve her yerde tüketiciye ulaşılabilecek bir özelliğe de sahiptirler (Bamba ve Barnes, 2007, s. 818).

Teknolojik gelişmeler ve özellikle internetin yaygınlaşması geleneksel pazarlama anlayışının değişmesini sağlamıştır. Önceleri ürün ve hizmet tanıtımı için geleneksel mecralar ön plandayken, dijitalleşen anlayışla birlikte pazarlama için yeni mecralar ortaya çıkmaya başlamıştır. Mobil pazarlama da bu alanda en çok kullanılan mecralardan birini oluşturmaktadır. Mobil pazarlamanın geleneksel mecralara göre en büyük faydası etkileşimli iletişime olanak tanıyor olmasıdır. Böylelikle tüketici ile firma arasında 
daha yakın bir ilişkinin kurulması kolaylaşmaktadır. Bunun yanı sıra mobil pazarlamada kullanıcıların izni alınarak reklam mesajları hedef kitleye iletilmektedir. Kişi eğer istemezse bu mesajları engelleyebilmektedir. Bu nedenle mobil pazarlama aracılığıyla sunulan reklam mesajlarının kabul oranı geleneksel mecraya oranla daha yüksektir. Yine aynı şekilde geleneksel mecralardaki reklam yayınlatma ücretine göre mobil pazarlama aracilığyla hedef kitleye ulaşmak daha uygun maliyettedir. Bunun yanı sıra gönderilen reklam mesajının etkili olup olmadığını ölçmek daha kolaydır. Bu tür avantajlardan dolayı markalar tarafindan hedef kitleye ulaşmak adına, mobil pazarlama ve mobil pazarlamanın en çok kullanılan uygulaması olan SMS reklamları sıklıkla kullanılmaktadır.

Mobil cihazlar son derece kişisel ve önemli iletişim araçları olarak değerlendirilmektedir. Bu bağlamda mobil cihazlar her an ve her yerde kullanıcıların yanında bulunup aktif bir şekilde kullanılmaktadır (Bacile ve Swilley, 2014, s. 118). Böylelikle tüketicilerin her zaman ve her yerde dijital varllğını sağlayan mobil cihazlar, pazarlamacılara da tüketicilere doğrudan ve sürekli olarak erişmesine imkân sunmaktadır (Grewal, Bart, Spann ve Zubcsek, 2016, s. 3). Bu durumun sonucu olarak mobil mecralar tüketiciye ulaşma noktasında birebir pazarlama için en önemli ortamlardan biri konumuna gelmiştir (Cortes ve Vela, 2013, s. 109). Bunun yanı sira Barnes ve Scornavacca (2004, s. 130), mobil pazarlamanın tematik hedef kitlelere ulaşılması ve mesajların kişiye özel uyarlanmasını sağladığı için daha etkili sonuçlar elde edilmesini kolaylaştırdığını vurgulamaktadır.

Mobil iletişim teknolojilerindeki çarpıcı gelişmeler, markaların tüketicilerle iletişim biçimlerinde değişikliklere yol açmıştır. Özellikle cep telefonu teknolojisindeki gelişmeler, markaların müşterilere ulaşması için yeni bir iletişim kanalı ortaya çıkarmıştır. Cep telefonları ve diğer taşınabilir dijital cihazların, özellikle genç ve genç yetişkin tüketiciler için temel bir ihtiyaç haline gelmesi, bu cihazların reklam aracı olarak kullanılmasını neredeyse zorunlu hale getirmiştir. Böylelikle mobil pazarlama ve SMS reklamcllı̆ı hedef kitleye ulaşma noktasında önemli bir rolü üstlenmiştir. Bu bağlamda günümüz koşulları içinde geleneksel medyada sunulan reklamlar ile karşılaştırıldığında mobil reklamların marka ve tüketici iliş̧kilerinin geliştirilmesi açısından daha uygun olduğu gözlemlenmektedir (Tekkanat ve Topaloğlu, 2016, s. 33). Haghirian ve diğerlerine (2005, s. 2) göre mobil reklamcillğın temel düzeyde kişiselleştirme ve etkileşim olmak üzere iki karakteristik özelliği vardır. Mobil reklamcılık kişiselleştirme için en uygun ortamı sağlamaktadır. Çünkü mobil cihazlar genellikle kullanıcının belirlediği kimliğini taşımaktadır. Dolayısıyla mobil reklamcılık sayesinde, mesajlar ve içerik özelleştirilebilmektedir. Ayrıca mobil reklamcılık uygulamaları, markaların tüketiciden hızlı ve doğrudan bir geri bildirim almasına izin verdiğinden etkileşim olanaklarını arttırmaktadır. Bu bağlamda mobil reklamclık sürecinde dijitalleşen metinler, görüntüler, sesler interaktif ve kişiselleştirilmiş bir şekilde kullanılmaktadır. Özetle cep telefonu hedef kitleye her zaman ve her yerde erişmeye imkân veren kişisel bir cihaz olduğu için mobil reklamcilık uygulamaları da kişiselleşen bir yapiya sahiptir (Tsang, Ho ve Liang, 2004, s. 68).

Mobil reklamcilığı ortaya çıkmasında en büyük etken geleneksel medyanın gün geçtikçe etkinliğini yitirmesi olarak kabul edilmektedir. Bu durumda reklamverenler, hedef kitlenin dikkatini çekecek reklamların oluşturulmasının yanı sıra reklam araçlarının seçiminde de daha yaratıcı olmak durumunda kalmıştır. Bu gelişmeler ekseninde reklamverenler için yeni ortamlar yaratma ihtiyacı mobil reklamcilı̆̆ın özellikle SMS (Short Message Service) reklamları gibi yeni kanalların ortaya çıkarılmasını tetiklemiştir (Van der Waldt, Rebello ve Brown, 2009, s. 444). SMS reklamları, mobil pazarlamanın ilk ve en yaygin kullanılan biçimi olarak kabul edilmektedir. SMS reklamları başlangıçta basit bir şekilde, mevcut ve potansiyel müşterilerin cep telefonlarına iletilen bir reklam mesajını temsil ederken günümüzde reklam kampanyalarında değişik yollarla ve sıklıkla kullanılan bir reklam türü olarak değerlendirilmeye başlanmıştır. Bu bağlamda günümüzde SMS'in gücü; televizyon, radyo, açıkhava, gazete reklamları gibi geleneksel olan ancak etkileşimli olmayan ortamlar aracıllğıyla yayınlanan reklam içeriğine etkileşim kazandırmak için kullanılmaktadır. Ström ve diğerlerine (2014, s. 1005) göre bu sayede mobil pazarlama ve SMS reklamları marka imaj1 yaratımında ve konumlandırmada, tüketiciye sunulacak tekliflerin, ürün çeşitliliğinin ve fiyatların duyurumu konusunda etkin bir rol üstlenmeye başlamıştır.

Zhang ve Mao'ya (2008, s.788) göre ise SMS reklamları cep telefonu cihazlarına metin mesajlarını göndermeye ve yanıtlamaya izin veren özel bir mobil pazarlama şeklidir. SMS reklamlarının tüketiciye her koşulda ulaşabilmesi, düşük maliyeti ve kişiselleştirme gibi çeşitli avantajları, markaların bu mecraya daha fazla yönelinmesi konusunda motive edici olmuştur (Rettie ve Brum, 2001). Böylece SMS teknolojisi tüketicilere, direkt gönderilen kişisel mesajlar aracilığıyla ürün, hizmet ve fikirlerin çekici kılınmasını sağlamıştır (Sultan, Rohm ve Gao, 2009, s. 309). Bugüne kadar yaşanan tüm gelişmeler neticesinde reklamverenler, cep telefonu kullanıcılarının demografik bilgileri ve mobil cihaz kullanım biçimlerine 
dayanarak, hedef kitlelerine zaman ve mekan kısıtlaması olmaksızın kişiselleştirilmiş reklam mesajlarını sıklıkla göndermektedir (Peters, Amato ve Hollenbeck, 2007, s. 130). Ayrıca, SMS reklamları, diğer geleneksel medyaları güçlendirmek için de yaygın olarak kullanılmaktadır (Zhang ve Mao, 2008, s. 788; Phau ve Teah, 2009, s. 99). SMS reklamları sayesinde markalar kendileri hakkında daha fazla bilgiyi ve herhangi bir değişimi; indirimleri, özel teklifleri, yarışmaları hedef kitlesiyle paylaşabilmektedir.

Ducoffe ve Curlo'ya (2000, s.247) göre reklam mesajları, reklamverenler ve tüketiciler arasındaki iletişim alışverişini ifade etmektedir. Mobil reklamcıllkta dikkat edilmesi gereken önemli bir nokta içeriğin hedef kitleye uygun olmasıdır. Ayrıca tüketiciye iletilen reklam mesajı özgün ve hedef kitle tarafindan anlaşılacak bir dilde olmalıdır (Haghirian, Madlberger ve Tanuskova 2005, s. 4). Diğer taraftan gönderilen mesajın özgün ve eğlenceli olması da önemlidir. Böylelikle tüketicilerin dikkatini ürüne/hizmete çekmek çok daha kolaylaşmaktadır (Heinonen ve Strandvik, 2007, s. 16-17; Carroll, Barnes, Scornavacca ve Fletcher, 2007, s. 82). Gönderilen mesajların bilgilendirici ve güvenilir olması da tüketicilerin ilgisini mesaja çekmeyi kolaylaştırmaktadır. SMS reklamlarının etkili olabilmesi için bu mesajların rahatsız edici özellikler taşımamasına ve anlaşılır olmasına dikkat etmek gerekmektedir. Çünkü anlaşılmaz bir mobil reklam mesajının neden olduğu rahatsızlık, algilanan marka değerine olumsuz olarak yansiyacaktır (Haghirian ve diğ., 2005, s. 4-5). Son olarak SMS reklamlarını hedef kitleye iletilirken mobil cihaz kullanıcısının izninin alınması ve uygun bir zamanda gönderilmesi gibi iki önemli unsur da kesinlikle göz önünde bulundurulmalıdır (Clow ve Baack, 2016, s. 231). Tüketiciler tarafindan bazen olumlu bazense olumsuz olarak değerlendirilebilen SMS reklamları, markalar adına hızlı ve etkin bir pazarlama aracı olarak ön plana çıkmaktadır. Reklam içerikli SMS kullanmanın çeşitli amaçları vardır. Bunlar; marka farkındalığı yaratma, ürün/hizmet ve bilgi talebi alma/paylaşma, markayla ilgili güncel haberleri iletme, yarışmalar veya anketler yapma ve özel teklifler sunma şeklinde belirtilmektedir. (Barwise ve Strong, 2002, s. 17). Reklamverenler adına SMS reklamcılığının en önemli faydalarından biri, SMS reklamlarının maliyetinin düşük olmasıdır. SMS reklamcıllğının düşük maliyeti istenilen hedef kitleye ulaşma ve markayla hedef kitle arasında yüksek bir etkileşim oranı elde etmeyi kolaylaştırmaktadır (Kavassalis vd., 2003, s. 62-63). Ayrıca, SMS reklamları, reklamverenler için hedef kitle analizi ve tüketicilerin mevcut ihtiyaçlarını saptama gibi önemli verilerin elde edilmesini mümkün kılmaktadır (Tekkanat ve Topaloğlu, 2016, s. 33). Bu bağlamda markalar hedef kitleye SMS reklamları göndererek mobil telefonların avantajını sıklıkla kullanmaktadır. Örneğin bir restoranın öğle ya da akşam yemeğine yakın gönderdiği özel menüsünü içeren bir SMS, hedef kitleyi restoranı ziyaret etmeye ikna eden bir araç olabilmektedir. Özetle çıkış noktasına bakıldığında SMS sistemi ağırlıklı olarak insanlar arasında bir iletişim aracı olarak kullanılmıştır. Ancak, markalar müşteri portföyünü genişletmek ve hedef kitlelerini etkileyebilmek için SMS reklamlarını etkin bir şekilde kullanmaya başlanmıştır. Böylelikle SMS reklamları, SMS teknolojisini kullanan mobil pazarlamanın ilk ve en yaygın kullanılan uygulaması olmuştur.

\section{Araştırma Tasarımı}

Dijitalleşen dünyada geleneksel reklam mecralarının etkisinin azalması buna karşın maliyetlerinin artması sonucunda, markalar yeni mecralara ihtiyaç duymuştur. Böylelikle, tüketicilere direkt ulaşma imkânı sağlayan mobil reklamcılık uygulamaları alternatif ve önemli bir mecra konumuna gelmiştir. Bu durumun sonucunda zaman ve mekân kısıtlaması olmaksızın kişiselleştirilmiş mesajlarla tüketicilere ulaşma imkanı sağlayan SMS reklamları, markalar tarafindan yoğun bir şekilde kullanılmaya başlanmıştır. Doğru bir şekilde kullanıldığında markaya büyük katk1 sağlayan SMS reklamları aksi durumda ise markaya zarar verebilmektedir. Bu bağlamda SMS reklamı kullanmaya karar veren markaların tüketici eğilimlerini ölçmesi oldukça büyük önem arz etmektedir. Yoğun bir şekilde kullanılmasına rağmen çeşitli değişkenlere göre farklılık gösteren tüketici eğilimlerinin reklam mesajları oluşturulurken ve tüketicilere iletilirken markalar tarafından yeterince dikkate alınıp alınmadığı önemli bir araştırma konusu haline gelmiştir. Bu kapsamda çeşitli değişkenlere göre SMS reklamlarına yönelik tüketici eğilimlerinin saptanması sorunsalı bu çalışmanın temel problemini oluşturmaktadır.

\section{Araştırmanın Amacı ve Alt Amaçları}

SMS reklamlarına yönelik üniversite öğrencilerinin eğlimlerinin ne yönde olduğunun belirlenmesi bu araştırmanın genel amacıdır. Ayrıca belirlenen eğilimlerin çeşitli değisskenler bağlamında ne yönde şekillendiğinin (pozitif/negatif) ortaya çıkarılması da araştırmanın bir diğer amacıdır. Araştırmanın alt amaçları ise aşağıdaki araştırma sorularına cevapların aranmasıdır.

1. SMS reklamlarıla en çok hangi sektöre yönelik mesaj iletilmektedir?

2. SMS reklamlarının en çok geldiği sektör cinsiyete göre değişir mi? 
3. SMS reklamındaki marka/ürün/hizmet hatırlanıyor mu?

4. SMS reklamlarına yönelik öğrencilerin genel eğilimleri (pozitif/negatif) ne yöndedir?

\section{Araştırmanın Önemi}

Her geçen gün dijitalleşen dünyada, markalar tarafindan tüketicilere ulaşmak için kullanılan geleneksek mecralar (televizyon, radyo, gazete) hem yetersiz hem de oldukça maliyetli bir konuma gelmiştir. Bu noktada markalar için alternatif olarak ortaya çıkan mobil reklamcillk giderek markalar tarafindan yoğun bir şekilde kullanılmaya başlanmıştır. Ancak bir mobil reklam türü olan kısa mesaj servisiyle (SMS) tüketicilere ulaşma yöntemine yönelik tüketici eğilimlerinin ne yönde olduğu konusunda henüz kesin bir sonuca ulaşılamamıştır. Bununla birlikte bu süreç içerisinde izin alma, güvenlik ve gizlilik gibi etik konular tüketici eğilimlerini değiştirebildiğinden hassas bir dengenin sağlanması gerekmektedir. Aksi takdirde tüketicilerin markaya yönelik tutumları negatif yönde şekillenebilir bu durumun sonucunda ise tüketici satın alma davranışından kaçınabilir. Bu bağlamda kısa mesaj yöntemi ile yapılan mobil reklamlara yönelik tüketici eğilimlerini yönlendiren farklı değişkenlerin ortaya çıkarılması gerekmektedir. Bu kapsamda araştırma sayesinde elde edilecek veriler ile markalar tarafindan mobil reklamcilığın daha etkin bir şekilde kullanılacak olmasından dolayı çalışmanın önemli olduğu düşünülmektedir. Ayrıca bu çalışma, konuyla ilgili gelecekte akademik çalışma yapma yöneliminde olan araştırmacılara önemli veriler sunması açısından da önem arz etmektedir.

\section{Sayıltılar}

Araştırmaya katılan öğrencilerin anket sorularına doğru cevap verdikleri kabul edilmiştir.

\section{Sinirliliklar}

1. Söz konusu araştırma zaman ve maddi kısıtlardan dolayı Ege Üniversitesi İletişim Fakültesi'nde öğrenim gören öğrencilerle sinırlıdır.

2. Elde edilen verilerin güvenirlik ve geçerliliği, cevaplayanların doğru ve kesin bilgiler vermesi ve araştırmada kullanılan anketin özelliklerine bağlı olması ile sınırlıdır.

\section{Yöntem}

Bugün, sosyal bilimlerde bir araştırmay1 yürütmek tek bir araştırma modeliyle çözüm sunamayabilmektedir; bu nedenle araştırmanın amaç ve kapsamına uygun olarak betimsel (tanımlayıcı) ve bağıntısal araştırma modeli kullanılmıştır. Gerçeğin ne olduğunu bulmak ve var olan mevcut duruma anlam verilmesine dönük araştırma modeli olan betimsel araştırmalar, genellikle güncel sorunların çözümüne yönelik, pratikteki yararı gözetilerek yapılan uygulamalı araştırmalardır (Ural ve Kılıç, 2005, s. 8). Amacı pazar çevresiyle ilgili doğru ve tam bilgiler elde etmektir (Nakip, 2003, s. 41). Bağıntısal araştırmalar ise iki veya ikiden fazla değişken arasındaki ortak bağ üzerinde durmaktadır (Erdoğan, 2012, s. 140). Araştırma probleminde yer alan iki ya da daha fazla değişkene ilişkin olarak örnek kütledeki katıllımcilardan veri toplanır ve toplanan veriler arasındaki ilişkileri görmek amacı ile analiz edilirler. Bağıntısal araştırmalarda toplanan verilerin istatistiksel tekniklerle incelenmesi sonucunda değişkenler arasında bir bağlantı olup olmadığı belirlenir. Üniversite öğrencilerinin SMS reklamlarına ilişkin tutum ve davranışlarının belirlenmesi için en uygun model betimsel modeldir. Öğrencilerin mobil reklam uygulamalarına yönelik tutumları betimleyici bir nitelik taşımaktadır. Davranış ve tutumlar arasındaki ilişkilerin belirlenmesi ise bağıntısal model ile açıklanmaktadır. Öğrencilerin SMS reklam uygulamalarını onaylayıp onaylamadıkları, en çok hangi sektörden reklam içerikli mesaj aldıkları ve içeriklerinin neler olduğunun belirlenmesi betimleyici bir nitelik taşımaktadır. Öğrencilerin tutum ve davranışları arasındaki ilişkilerin belirlenmesi ise bağlantısal model ile açıklanacaktır.

\section{Evren ve Örneklem}

Araştırmanın evrenini İzmir ilindeki Ege Üniversitesi İletişim Fakültesi'nin tüm öğrencileri oluşturmaktadır. Ancak maddi kısıtlar ve zaman sınırlılı̆̆ gibi nedenlerden dolayı evreni temsil etmesi için kolayda örnekleme yöntemiyle belirlenen öğrencilerden oluşan örneklem grubundan elde edilen veriler çalışma kapsamında analiz edilmiştir. Örneklem grubunun sayısı ise Krejcie ve Morgan (1970) tarafindan nüfusa göre örneklem grubunun sayısının belirlenmesi için oluşturdukları tablo esas alınarak belirlenmiştir. $\mathrm{Bu}$ tabloya göre evreni temsili açısından 322 kişi yeterli bir saydır. Ancak yaygin fakat her zaman geçerli olmayan görüş, örneklem büyüklüğü arttıkça tahmin sonuçlarının daha isabetli olacağı kanısıdır (Gürbüz ve Şahin, 2017, s. 123). Buna göre evrendeki 1969 öğrenciden 395 öğrenciye anket uygulanmıştır. Anket uygulanan öğrencilerin 200’ü kadın 195’i ise erkek öğrencilerden oluşmaktadır. 


\section{Veri Toplama Arac1}

Bu çalışmadaki veriler, reklam araştırmalarında gerekli bilgileri elde etmek için sıklıkla kullanılan bir araç olan anket ile toplanmıştır. Güzeler'in (2010) mobil pazarlama ile ilgili yazdığı yüksek lisan tezinde kullanılan anket formu güncellenerek bu çalışma kapsamında kullanılmıştır. Bu bağlamda anket formunu kullanmak için kendisinden mail yoluyla izin alınmıştır. Anket formu ve ölçekte güncelleme yapıldıktan sonra örneklemi temsil eden 35 kişilik bir grupta ön test yapılmıştır. Sonrasında güvenilirliği belirlemek amacıyla Cronbach $\alpha$ değeri hesaplanmıştır. Hesaplama sonunda 0,95'lik bir değer elde edilmiştir. Bu değer ölçeğin yüksek derecede güvenilir ve geçerli olduğunu göstermektedir. Anket formu, katıllımcıların mobil pazarlamaya ilişkin eğilimlerini ölçmek için 5'li likert ölçeği ile hazırlanan 20 sorunun yanı sıra 9 tane demografik soru içermektedir.

\section{Verilerin Toplanması ve Analizi}

Anket formu son haline getirildikten sonra verilerin toplanması aşamasına geçilmiştir. Bu bağlamda çalışma kapsamında kullanılan veriler, Ege Üniversitesi İletişim Fakültesi’nde okuyan gönüllü öğrencilere dağıtılan ölçme arac1 yoluyla toplanmıştır. Verilerin analizi ise Windows işletim sisteminde SPSS programında yapılmıştır. SPSS'de yapılan frekans analizleri soncunda elde edilen bulgular makalenin ilgili bölümünde okurlarla paylaşılmışır.

\section{Bulgular ve Yorumlar}

Katılımcıların \%50,6'sını kadın öğrenciler oluştururken \%49,4’ünü ise erkek öğrenciler oluşturmaktadır. Katılımcıların yaş ortalaması ise 20 'dir. Katılımcıların aylık ortalama gelirleri 500 lira ile 2000 lira üstü arasında değişmektedir. Katılımcıların aylık ortalama gelirleri ise 682,9 liradır. Katılımcıların \%25,8’i Halkla İlişkiler ve Tanıtım, \%24,6's1 Reklamcılık bölümünde eğitim görmektedir. Ankete katılan Gazetecilik bölümü ile Radyo, Televizyon ve Sinema bölümü öğrencilerinin oranıysa \%24,8'dir. Katıllımc1 öğrencilerin sınıfları açısından yüzde değerlerine bakılacak olunursa \%25,3'ü dördüncü, \%25,1'i birinci, \%24,8’i ise ikinci ve üçüncü sınıflardan oluşmaktadır. Bu bağlamda örneklemin evrendeki dağılımının çeşit ve oran yönünden oldukça benzer olduğu görülmektedir. Ayrıca örneklem büyüklüğü bu araştırma için yeterli sayısının üzerindedir. Böylelikle örneklemin evreni temsil yeteneğine sahip olduğu söylenebilir.

Tablo 1. Katulmonclarn Demografik Özellikleri ( $n=395)$

\begin{tabular}{|c|c|c|c|}
\hline Değiskeen & Düzey & & \\
\hline \multirow{2}{*}{ Cinsiyet } & Erkek & 195 & $\overline{49,4}$ \\
\hline & Kadın & 200 & 50,6 \\
\hline \multirow{4}{*}{ Yaş } & $17-20$ & 127 & 32,2 \\
\hline & $21-24$ & 244 & 61,8 \\
\hline & $25-28$ & 18 & 4,6 \\
\hline & $29^{+}$ & 6 & 1,5 \\
\hline \multirow{5}{*}{ Aylık Ortalama Gelir } & $500 \mathrm{TL}$ & 84 & 21,3 \\
\hline & $501-1000 \mathrm{TL}$ & 152 & 38,5 \\
\hline & $1001-1500 \mathrm{TL}$ & 93 & 23,5 \\
\hline & $1501-2000 \mathrm{TL}$ & 39 & 9,9 \\
\hline & 2001 TL ve üzeri & 27 & 6,8 \\
\hline \multirow{4}{*}{ Bölüm } & Gazetecilik & 98 & 24,8 \\
\hline & Halkla İlişkiler ve Tanıtım & 102 & 25,8 \\
\hline & Radyo, Televizyon ve Sinema & 98 & 24,8 \\
\hline & Reklamcilık & 97 & 24,6 \\
\hline \multirow{4}{*}{ Sinif } & 1 & 99 & 25,1 \\
\hline & 2 & 98 & 24,8 \\
\hline & 3 & 98 & 24,8 \\
\hline & 4 & 100 & 25,3 \\
\hline
\end{tabular}

Katılımclların \%43’ü Türk Telekom mobil operatörünü kullanırken, \%32,9’u Vodafone, \%23,3’ü ise Turkcell kullanmaktadır. Katılımcılara toplamda \%29,1 ile en çok telekomünikasyon sektöründen mesaj gelmektedir. Bu sektörü sırasıyla \%16,5 ile finans ve \%15,9 ile kozmetik sektörü izlemektedir. En az mesaj gelen sektör ise \%0,3 ile otomobil ve \%0,5 ile de sağlık sektörü olmuştur. Cinsiyet bazında bakılacak olursa kadınların \%31,5’i kozmetik sektöründen SMS reklam mesajları aldığını ifade ederken, erkeklerin \%31,8’i ise telekomünikasyon sektöründen SMS reklam mesajları aldıklarını ifade etmiştir. Bu durum hedef kitle bölümlendirmesinin reklamverenler tarafından dikkatli bir şekilde yapıldığını ortaya koymaktadır. 
SOLAK ve AKYOL

Mobil Pazarlamanın İlk Uygulaması Olan SMS Reklamlarına Yönelik Ĕ̆ilimlerin Saptanması: Üniversite Öğrencileri Üzerine Bir Inceleme

Tablo 2. Cinsiyete Göre Sektörel Bazda Gelen SMS Reklamlar

\begin{tabular}{|c|c|c|c|}
\hline \multirow{2}{*}{ Sektörler } & \multicolumn{2}{|c|}{ Cinsiyet } & \multirow[b]{2}{*}{ Toplam } \\
\hline & Erkek & Kadın & \\
\hline \multirow{2}{*}{ Gida } & 5 & 7 & 12 \\
\hline & $1,3 \%$ & $1,8 \%$ & $3,0 \%$ \\
\hline \multirow{2}{*}{ Giyim } & 20 & 32 & 52 \\
\hline & $5,1 \%$ & $8,1 \%$ & $13,2 \%$ \\
\hline \multirow{2}{*}{ Kozmetik } & 0 & 63 & 63 \\
\hline &, $0 \%$ & $15,9 \%$ & $15,9 \%$ \\
\hline \multirow{2}{*}{ Finans } & 46 & 19 & 65 \\
\hline & $11,6 \%$ & $4,8 \%$ & $16,5 \%$ \\
\hline \multirow{2}{*}{ Telekomünikasyon } & 62 & 53 & 115 \\
\hline & $15,7 \%$ & $13,4 \%$ & $29,1 \%$ \\
\hline \multirow{2}{*}{ Sağlık } & 1 & 1 & 2 \\
\hline &, $3 \%$ &, $3 \%$ &, $5 \%$ \\
\hline \multirow{2}{*}{ Turizm } & 3 & 6 & 9 \\
\hline &, $8 \%$ & $1,5 \%$ & $2,3 \%$ \\
\hline \multirow{2}{*}{ Otomotiv } & 1 & 0 & 1 \\
\hline &, $3 \%$ &, $0 \%$ &, $3 \%$ \\
\hline \multirow{2}{*}{ Eğitim } & 7 & 2 & 9 \\
\hline & $1,8 \%$ &, $5 \%$ & $2,3 \%$ \\
\hline \multirow[t]{2}{*}{ Teknoloji-elektronik } & 13 & 7 & 20 \\
\hline & $3,3 \%$ & $1,8 \%$ & $5,1 \%$ \\
\hline \multirow{2}{*}{ Diğer } & 37 & 10 & 47 \\
\hline & $9,4 \%$ & $2,5 \%$ & $11,9 \%$ \\
\hline \multirow{2}{*}{ Toplam } & 195 & 200 & 395 \\
\hline & $49,4 \%$ & $50,6 \%$ & $100,0 \%$ \\
\hline
\end{tabular}

Bunun yanı sıra katılımcıların \%18,5’i kozmetik sektöründen gelen mesajların ilgisini çektiğini ifade ederken, \%18,2'si ise giyim sektöründen gelen SMS'leri ilgi çekici olarak belirtmiștir. \%1,3 ile otomotiv ve $\% 1,8$ ile sağlık sektörleri en düşük ilgi çekiciliğge sahip sektörler olarak yer almıştır. Yukarıda da görüldüğü üzere sektör nezdinde değerlendirme yapıldığında bu düşüklüğün gelen mesaj sayısıyla doğru bir orantıda olduğu tespit edilmiștir. Otomotiv sektörden alınan mesajların oranının düșük olmasının sebebi, öğrencilerin birçoğunun henüz kendine ait bir arabasının olmaması bu nedenle markaların hedef kitle değerlendirmesi içine girmemelerinden kaynaklandığı düşünülmektedir. Benzer şekilde öğrenciler, sağlık sektörü nezdinde de markaların hedef kitle bölümlendirmesine girmemektedir. Çünkü öğrenciler sağllk hizmetlerinden aileleri üzerinden faydalanmaktadır. Bu sebeple öğrencilere sağlık sektörüne yönelik mesajlar da çok fazla gelmemektedir. Cinsiyetler açısından bakılacak olursa \%35,5 ile kozmetik sektörü kadınların en çok ilgisini çeken mesajları gönderen sektörken, erkekler de ise \%21,5 ile ankette belirtilen sektörlerin dışında kalan diğer seçeneği en çok ilgiyi çeken mesajları gönderen sektör olarak ortaya çıkmıştır. Bu durumda hedef kitle bölümlendirmesinin kadınlar açısından uygun olarak yapıldığını göstermektedir. Erkekler açısından en çok ilgi çeken ikinci sektör ise teknoloji-elektronik sektörü $(\% 20,5)$ olarak belirtilmiştir. Erkeklere en çok mesajin geldiği telekomünikasyon sektöründen ziyade, az oranda bir mesajın geldiği teknoloji-elektronik $(\% 6,7)$ sektörünün daha ilgi çekici olması da mesajın sayısı ve yoğunluğundan çok kişilerin ilgi alanlarının mesajların okunmasında ve akılda kalmasında etkili olduğunu ortaya koymaktadır. Cep telefonuna gelen mesajların içeriği en çok kampanyalara yönelik mesajlardan oluşmaktadır. Hem erkeklerde $(\% 64,1)$ hem de kadınlarda (\%52) kampanyalara yönelik mesajların yoğun olarak geldiği görülmüştür. Bunun yanı sıra indirimlere yönelik mesajlar (erkeklerde \%25,1; kadınlarda $\% 41,5)$ ikinci en çok gelen mesaj içeriğini oluştururken; yeni ürün/hizmet tanıtımına yönelik gelen mesajlar (erkeklerde \%10,8; kadınlarda \%6,5) ise son sırada yer almaktadır.

\section{Frekans Analizi Sonuçları}

Ankette yer alan cep telefonu SMS reklamlarına yönelik öğrencilerin genel düşüncelerini ortaya çıkarmak adına 5'li likert ölçeği kullanılarak uygulanan faktörler ve katılım yüzdeleri Tablo 3'de yer almaktadır. Tabloda kesinlikle katıllyorum ve katıllyorum seçeneği ile kesinlikle katılmıyorum ve katılmıorum seçeneklerinin yüzdeleri toplanarak bir arada verilmiştir. Ayrıca verilen cevapların ortalamaları ve standart sapmaları da ankete cevap verenlerin genel eğilimlerinin kattlı katılmama noktasında hangi yönde olduğunu belirtmek adına tabloya eklenmiştir. 
Tablo 3. Frekans Analiri, Ortalama ve Standart Sapma Sonuclarn

\begin{tabular}{|c|c|c|c|c|c|}
\hline İFADELER & 总 & 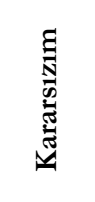 & 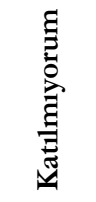 & $\begin{array}{l}\frac{\pi}{5} \\
\frac{\pi}{\pi} \\
0 \\
0\end{array}$ & 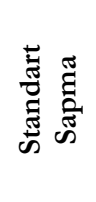 \\
\hline $\begin{array}{l}\text { 1) SMS yoluyla cep telefonuma gelen ve önemli olduğunu } \\
\text { düşündüğüm reklam içerikli mesajı başkalarına da iletirim. }\end{array}$ & $\% 28,3$ & $\% 9,1$ & $\% 62,5$ & 2,35 & 1,35 \\
\hline $\begin{array}{l}\text { 2) SMS yoluyla gelen reklam iletileri ilgi duyduğum ürün veya } \\
\text { hizmetlerden daha hızlı haberdar olmamı sağlar. }\end{array}$ & $\% 68,1$ & $\% 16,5$ & $\% 15,5$ & 3,59 & 1,01 \\
\hline $\begin{array}{l}\text { 3) Gelen mesajlar doğrultusunda reklamı yapılan ürün veya hizmeti } \\
\text { satın almaya yönelirim. }\end{array}$ & $\% 20,8$ & $\% 38,7$ & $\% 40,5$ & 2,69 & 1,01 \\
\hline $\begin{array}{l}\text { 4) Cep telefonuma gelen reklamların görüntülü (MMS) olarak } \\
\text { gönderilmesi satın alma davranışıma daha olumlu etkide bulunur. }\end{array}$ & $\% 19$ & $\% 21,8$ & $\% 59,3$ & 2,34 & 1,17 \\
\hline $\begin{array}{l}\text { 5) Cep telefonuma gönderilen reklam içerikli mesajlar söz konusu } \\
\text { ürünün/hizmetin aklımda kalmasını sağlar. }\end{array}$ & $\% 53$ & $\% 21,5$ & $\% 25,6$ & 3,27 & 1,10 \\
\hline $\begin{array}{l}\text { 6) SMS yoluyla yapılan reklamlar, içerikleri nasıl hazırlanırsa } \\
\text { hazırlansın, satın alma kararımı etkilemez. }\end{array}$ & $\% 33,4$ & $\% 31,1$ & $\% 35,5$ & 3,07 & 1,13 \\
\hline $\begin{array}{l}\text { 7) Reklam içerikli mesajlardan rahatsız olmam durumunda, ne gibi } \\
\text { yasal haklara sahip olduğumu biliyorum. }\end{array}$ & $\% 48,6$ & $\% 18$ & $\% 33,4$ & 3,24 & 1,30 \\
\hline $\begin{array}{l}\text { 8) Reklam içerikli mesajların yaratıcı bir içeriğe sahip olması } \\
\text { ürünün/hizmetin daha çok aklımda kalmasını sağlar. }\end{array}$ & $\% 69,3$ & $\% 15,9$ & $\% 14,7$ & 3,76 & 1,09 \\
\hline $\begin{array}{l}\text { 9) İçeriği ne olursa olsun, geç saatlerde veya tatil günlerinde } \\
\text { gönderilen reklam içerikli mesajlara tepkim hep olumsuz olur. }\end{array}$ & $\% 51,4$ & $\% 22,5$ & $\% 26,1$ & 3,50 & 1,27 \\
\hline $\begin{array}{l}\text { 10) Kısa mesaj yoluyla iletilen reklam mesajlarında } \\
\text { ürünün/hizmetin fiyatı net olarak belirtilmelidir. }\end{array}$ & $\% 80,8$ & $\% 10,1$ & $\% 9,1$ & 4,16 & 1,01 \\
\hline $\begin{array}{l}\text { 11) Gelen reklam içerikli kısa mesajlar ürün ve hizmetler hakkında } \\
\text { bilgi sahibi olmamı sağladığı için faydalı buluyorum. }\end{array}$ & $\% 45,8$ & $\% 28,6$ & $\% 25,6$ & 3,21 & 1,11 \\
\hline $\begin{array}{l}\text { 12) Markalar için form ve anket doldururken, reklam içerikli kısa } \\
\text { mesaj gönderileceğine dair ifadeye yer verilmelidir. }\end{array}$ & $\% 78$ & $\% 12,2$ & $\% 9,9$ & 4,11 & 1,03 \\
\hline $\begin{array}{l}\text { 13) Telefonuma SMS olarak gelen reklam içerikli kısa mesajları } \\
\text { okumadan silerim. }\end{array}$ & $\% 35,7$ & $\% 28,1$ & $\% 36,2$ & 3,03 & 1,18 \\
\hline $\begin{array}{l}\text { 14) İznim ve isteğim dışında gelen mesajlar için ilgili markaya } \\
\text { şikâyette bulunurum. }\end{array}$ & $\% 30,9$ & $\% 25,6$ & $\% 43,4$ & 2,86 & 1,21 \\
\hline $\begin{array}{l}\text { 15) Telefonuma iznim ve isteğim dışında gelen mesajlar için yasal } \\
\text { yollara başvururum. }\end{array}$ & $\% 34,3$ & $\% 24,3$ & $\% 51,4$ & 2,63 & 1,20 \\
\hline $\begin{array}{l}\text { 16) Markalar tarafindan gönderilen reklam içerikli mesajlar, iznim } \\
\text { dâhilinde gönderilirse beni rahatsız etmez. }\end{array}$ & $\% 64,2$ & $\% 14,2$ & $\% 16,2$ & 3,73 & 1,15 \\
\hline $\begin{array}{l}\text { 17) Cep telefonuma SMS yoluyla gelen reklam iletilerinden rahatsiz } \\
\text { olurum. }\end{array}$ & $\% 44,3$ & $\% 29,1$ & $\% 26,6$ & 3,29 & 1,15 \\
\hline $\begin{array}{l}\text { 18) Beni rahatsız ettiğini düşündüğüm mesajları gönderen markaya } \\
\text { tepki gösterir, ürününü/hizmetini asla satın almam. }\end{array}$ & $\% 28,6$ & $\% 25,6$ & $\% 45,8$ & 2,79 & 1,20 \\
\hline $\begin{array}{l}\text { 19) Çok sayıda reklam içerikli mesaj almam kullandığım GSM } \\
\text { operatörünü değiştirmeme sebep olabilir. }\end{array}$ & $\% 26,5$ & $\% 22,5$ & $\% 50,9$ & 2,66 & 1,26 \\
\hline $\begin{array}{l}\text { 20) Markalardan reklam içerikli SMS almanın, bana sosyal çevremde } \\
\text { saygınlık kazandırdığını düşünüyorum. }\end{array}$ & $\% 7,9$ & $\% 11,4$ & $\% 80,7$ & 1,72 & 1,03 \\
\hline
\end{tabular}

Tablo 3’te görüldügü üzere katılımcıların \%40,5’i SMS yoluyla gelen reklam mesajlarından haberdar olarak bir ürün ya da hizmeti satın alma davranışı göstermemektedir. Kararsızların yüzdesinin $(\% 38,7)$ yüksekliğini de göz önünde bulundurarak SMS reklam mesajlarının kişileri belli bir tüketime yönlendirmediği sonucuna ulaşılabilir. Diğer taraftan ortalama değere bakıldığında $(2,69)$ kararsızlı̆ga yönelik eğilimin de yüksek olduğu görülmektedir. Bu sonuç kararsızların SMS reklamlarına yönelik eğilimlerinin yaratıcı içerikle olumluya dönüştürülerek satın almaya yönlendirilebileceklerini göstermektedir. MMS reklam mesajlarına bakıldığındaysa satın alma davranışı üzerinde belli bir etkiye sahip olmadığı bulgusuna ulaşılmıştır. Ankete katılanların \%59,3’ü cep telefonuna gelen mesajların MMS olarak gönderilmesinin satın alma davranışlarına olumlu etkide bulunmadığını belirtmişlerdir.

Katılımciların \%53’ü SMS reklamlarının söz konusu ürün ya da hizmetin akıllarında kalmasını sağladığını belirtmektedir. SMS reklam mesajları ürün ya da hizmetin akılda kalıcilığını sağlayarak, satın alma noktasında tüketicilerin reklamı yapılan ürünü tercih etmelerine katk1 sağladığ1 düşünülmektedir. Ayrıca katılımcıların \%69,3’ü yaratıc1 içeriğe sahip SMS reklam mesajlarının ürün ya da hizmetin akılda kalıcılı̆̆ını daha fazla arttırdığını ifade etmiştir. Bu da SMS reklam mesajlarının sıradanlıktan çıkıp, özgün, 
eğlenceli ve hedef kitlenin anlayacağı bir tarzda olmasının ne kadar büyük bir öneme sahip olduğunu göstermektedir.

Katılımcıların \%68,1'i SMS reklamlarının ilgi duyduğum ürün veya hizmetlerden daha hızlı haberdar olmalarını sağladığını düşünmektedir. Benzer şekilde katılımcılar, markalardan gelen reklam içerikli SMS’leri ürün ve hizmetler hakkında bilgi sahibi olmalarını sağladığı için faydalı $(\% 45,8)$ bulmaktadır.

Katıllımciların \%44,3'ü cep telefonlarına gelen reklam iletilerinden rahatsız olduğunu belirtirken, cep telefonlarına gelen mesajları okumadan silenlerin oranı \%35,7'dir. Bu durum cep telefonuma gelen ve önemli olduğunu düşündügüm reklam içerikli mesajı başkalarına da iletirim sorusuna verilen \%62,5 katılmıorum oranıyla da desteklenmektedir. Katılımcılar kendilerine gelen mesajların ürün ya da hizmete yönelik akılda kalıcılığı, hatırlanırlığı sağladığını söylemesine rağmen, başkalarına bu mesajları iletme noktasında olumsuz bir tutum içerisinde olduklarını belirtmişlerdir.

Katıllımcilar izinleri dışında gelen SMS reklam mesajlarına karşı nasıl bir yasal yol izleyeceklerini $(\% 48,6)$ bilmektedir. Ancak katılımcıların büyük çoğunluğu $(\% 51,4)$ bu yasal yollara başvurmayı tercih etmemektedir. Ayrıca katılımcıların \%43,4’ü izni ve isteği dışında gelen mesajları ilgili markaya şikâyet etmeyi de tercih etmemektedir. Yani katılımcılar izinleri dışında gelen mesajlardan nasıl kurtulacaklarını bilmelerine rağmen bu yolu kullanmamaktadır. Bunun dışında çok sayıda reklam içerikli mesaj almanın operatör değişikliğine $(\% 50,9)$ yol açmadığını katılımcılar belirtmişlerdir. Böylelikle katılımcılar istemeden de olsa birçok markanın reklam mesajına maruz kalmaktadır. Bu bağlamda katılımcıların reklam mesajlarına yönelik olumsuz düşüncelerinde izinleri dışında gelen ve engellemedikleri mesajların etkisi olduğu söylenebilir. Çünkü katılımcıların \%64,2’si izinleri ve istekleri doğrultusunda gelen mesajlardan rahatsız olmadıklarını ankette belirtmişlerdir. Bu noktada ortaya çıan bir diğer sonuç ise katılımcıların kendilerini rahatsız ettiklerini düşündükleri markayı satın almamaya yönelik $\% 28,6$ ile çok düşük bir olumsuz eğilim ortaya koymuş olmalarıdır. Sonuç olarak katılımcılar gelen mesajlardan rahatsızlık duyup mesajı silmekte ancak satın alma kararında bu mesajların yaratığı olumsuz durumdan etkilenmemektedir.

\section{Tartışma, Sonuç ve Öneriler}

Cep telefonlarının yaygın kullanımı ve mobil teknolojideki gelişmeler markaların pazarlama faaliyetlerinde yeni bir mecradan faydalanmasına olanak sağlamıştır. Kişisel mobil telefonlar iletişimin sıklığını ve hızını artırmıştır. Bu bağlamda, özellikle mobil iletişim teknolojisindeki gelişmeler, markaların tüketicileriyle olan iletişim biçiminde de yenilikler ortaya çıkarmıştır. Böylece, mobil iletişim geleneksel iletişim amacını aşan ve pazarlama iletişimini destekleyen bir konuma gelmiştir. Pazarlama iletişimi sürecine hızla entegre edilen bu yeni mecra, markaların reklamlarının etkisini ölçmelerine ve daha az maliyetle etkin bir şekilde tüketicilere ulaşmalarına katkı sağlamaya başlamıştır. Mobil pazarlamanın ilk ve en yaygın kullanılan uygulaması olan SMS reklamlarına yönelik genç tüketici kitlesinin eğilimlerinin ne yönde olduğunun anlaşılması amacıyla hazırlanan bu çalışmada birçok yabancı ve yerli çalışmadan faydalanılmıştır. Bu bağlamda öncelikle derinlemesine bir literatür taraması sonrasında nicel analizler yapılmıştır. Araştırma sonucunda önemli bulgular edilmiştir. Araștırma bulguları hem önceki çalışmalarla kıyaslanmış hem de kendi özelinde değerlendirmeler yapılmışıı. Araştırma kapsamında elde edilen verilere göre SMS reklamlarının en çok geldiği sektörler sırasıyla; telekomünikasyon, finans ve kozmetiktir. Cinsiyet değişkeni bağlamında değerlendirme yapıldığında ise kadınlara en çok kozmetik sektöründen SMS gelirken erkeklere en çok telekomünikasyon sektöründen SMS gelmektedir. Bu kapsamda tüketicilere reklam içerikli mesaj gönderen markaların hedef kitle bölümlendirmesini doğru yaptığ1 söylenebilir. Çünkü ankette yer alan en çok hangi sektöre yönelik mesaj almak isterseniz sorusuna kadınların yüksek oranda kozmetik sektörü cevabı verdiği görülmektedir. Diğer tüm reklam kampanyalarında olduğu gibi doğru hedef kitleye uygun içerikle ulaşmak etkiyi artıracaktır. Bu noktada mobil mecralar markalara büyük kolaylık sağlamaktadır. Mobil cihazlar tamamen kişisel olduğu için tüketicinin cinsiyet, yaş, eğitim durumu gibi tüm demografik bilgilerine doğrudan ve kolaylıkla ulaşılabilir. Bu bağlamda uygun hedef kitleye reklam içerikli SMS’ler anında ve düşük maliyetle iletilebilmektedir. Bu araştırma sonucunda SMS reklamları katılımcıları satın alma kararına götüren bir ön hazırlık olan akılda kalıcılık noktasında önemli görülmektedir. Ancak katılımcılar satın alma kararını verirken salt SMS reklamlarından etkilenmediklerini $(\% 40,5)$ belirtmişlerdir. Bu noktada kararsız olanlarının oranı $(\% 38,7)$ oldukça yüksektir ve ortalama değer $(2,69)$ kararsızlar noktasına daha yakındır. Bu nedenle yaratıcı, kişiselleştirilmiş ve akılda kalıcı reklam mesajlarının kişileri satın almaya yönlendirmede daha etkili olacağı düşünülmektedir.

Araştırma bulgularına göre katılımcıların büyük çoğunluğu, izinli SMS reklamlarının kendilerini rahatsız etmediğini belirtmişlerdir. Ancak izinleri dışında gelen mesajların kendilerini rahatsız ettiğini ve bu 
noktada yasal haklarını bilmelerine rağmen herhangi bir tepkide bulunmadıklarını ifade etmişlerdir. Dikkat edilmesi gereken önemli nokta izinsiz gelen mesajların tüketicileri rahatsız ettiği ve markaya yönelik zihinlerinde olumsuz bir imaj oluşturabilme ihtimalinin olduğudur. Bu nedenle SMS temelli yürütülecek tüm reklam kampanyalarında reklam mesaj1 gönderilecek kişilerin izinlerinin alınması büyük önem taşımaktadır. Scharl ve diğerlerine göre de (2005, s. 168) bu tarz reklam gönderilerinin öncesinde tüketicilerin SMS tabanlı bilgi hizmetine katılmaya izin vermeleri ve süreç noktasında ikna edilmeleri gerektiğini belirtmektedir. Tüketicinin izni dışında gönderilen mesajlar, SMS reklamcıllğına yönelik tüketici tutumlarının olumsuz olmasına neden olmaktadır. Sonuç olarak tüketicilere iletilen SMS reklamlarına yönelik genel eğilimin olumlu olduğu görülmüştür. Özellikle gelen mesajların hatırlanabilir olması, ürün ve hizmetin akılda kalıcılığı noktasında katıllımcıların genel düşünceleri olumlu yöndedir. Ayrıca gelen mesajlar eğer katıllımcıların izinleri doğrultusunda gelmişse bu olumlu eğilim daha da artış göstermektedir. Ancak cep telefonu üzerinden yapilan reklam kampanyaları çok hassastır ve bu tür reklam uygulamasını tercih eden markaların kullanıcıları rahatsız etmeme konusunda dikkatli olmaları gerekmektedir (Jelassi ve Enders, 2004). Hem yabancı hem de yerli literatürde yapılan önceki çalışmalar incelendiğinde öne çıkan konu SMS reklamlarına yönelik eğilimin pozitif olması için tüketicilerden izin alınmasıdır. Önceki çalışmalardan elde edilen verilerle bu çalışmada elde edilen veriler de karşılaştırıldığında SMS gönderimi için tüketici rızasının oldukça önemli olduğu bir kez daha ispatlanmıştır. Bu bağlamda markaların ürünleri ya da hizmetleri hakkında bilgi aktarmak için tüketicilerden izin alarak SMS reklam mesajlarını kullanmalarının daha etkili ve uygun olacağı düşünülmektedir.

\section{Etik Beyan}

"Mobil Pazarlamanın İlk Uygulaması Olan SMS Reklamlarına Yönelik Eğilimlerin Saptanması: Üniversite Öğrencileri Üzerine Bir İnceleme" başlıklı çalışmanın yazım sürecinde bilimsel, etik ve alıntı kurallarına uyulmuş; toplanan veriler üzerinde herhangi bir tahrifat yapılmamış ve bu çalışma herhangi başka bir akademik yayın ortamına değerlendirme için gönderilmemiştir.

\section{Kaynakça}

American Marketing Association. (2013, Temmuz 1). American Marketing Association Web Sitesi: https://www.ama.org/AboutAMA/Pages/Definition-of-Marketing.aspx, 05.02.2019

Bacile, T. J. ve Swilley, E. (2014). From Firm-controlled to Consumer-contributed: Consumer Co-production of Personal Media Marketing Communication. Journal of Interactive Marketing, 28, 117-133. doi: 10.1016/j.intmar.2013.12.001

Bamba, F. ve Barnes, S. J. (2007). SMS Advertising, Permission And The Consumer: A Study. Business Process Management Journal, 13, 815-829. doi:10.1108/14637150710834578

Barnes, S. ve Scornavacca, E. (2004). Mobile Marketing: The Role Of Permission And Acceptance. International Journal of Mobile Communications, 2, 128-139. doi: 10.1504/IJMC.2004.004663

Barwise, P. ve Strong, C. (2002). Permission-Based Mobile Advertising. Journal of Interactive Marketing, 16, 14-24. doi: $10.1002 /$ dir.10000

Carroll, A., Barnes, J. S., Scornavacca, E. ve Fletcher, K. (2007). Consumer Perceptions And Attitudes Towards SMS Advertising: Recent Evidence From New Zealand. International Journal of Advertising, 26, 79-98. doi: 10.1080/02650487.2007.11072997

Clow, K. E. ve Baack, D. (2016). Bütünlesik Reklam, Tutundurma ve Pazarlama İetisimi (Çev. Gülay Öztürk). Ankara: Nobel Yayincllik.

Cortés, G. L. ve Vela, R. M. (2013). The Antecedents of Consumers' Negative Attitudes Toward SMS Advertising: A Theoretical Framework and Empirical Study. Journal of Interactive Advertising, 13, 109-117. doi: 10.1080/15252019.2013.826553

Çakır, F., Çakır, M. ve Çiftçi, T. E. (2010). Tüketicilerin SMS Reklam Mesajlarına Yönelik Tutum ve Davranışları. Organizasyon Ve Yönetim Bilimleri Dergisi, 2(1), 27-35.

Doğaner, M., \& Kuyucular, Y. (2017). Mobil Reklam Faaliyetlerinin Tüketici Alg1sı Üzerine Etkileri: Üniversite Öğrencilerine Yönelik Bir Araştırma. Adnan Menderes Üniversitesi, Sosyal Bilimler Enstitüsï Dergisi, 4(3), 236-255.

Ducoffe, R. H. ve Curlo, E. (2000). Advertising Value And Advertising Processing. Journal of Marketing Communications, 6 , 247-262. doi: 10.1080/135272600750036364

Erdoğan, İ. (2012). Poritivist Metodoloji ve Ötesi. Ankara: Erk Yayınları.

Gürbüz, S. ve Şahin, F. (2017). Sosyal Bilimlerde Araştrma Yöntemleri. Ankara: Seçkin Yayıncilık.

Grewal, D., Bart, Y., Spann, M. ve Zubcsek, P. P. (2016). Mobile Advertising: A Framework And Research Agenda. Journal of Interactive Marketing, 34, 3-14. doi: 10.1016/j.intmar.2016.03.003

Haghirian, P., Madlberger, M. ve Tanuskova, A. (2005). Increasing Advertising Value of Mobile Marketing: An Empirical Study of Antecedents. Proceedings of the 38th Anmual Hawaii International Conference on System Sciences (s. 110). Big Island, HI, USA,: IEEE Xplore. doi: 10.1109/HICSS.2005.311 
Heinonen, K. ve Strandvik, T. (2007). Consumer Responsiveness to Mobile Marketing. International Journal of Mobile Communications, 5, 1-17. doi: 10.1504/IJMC.2007.014177

İspir, N. B. ve Suher, H. K. (2009). SMS reklamlarına yönelik tüketici tutumları. Selcuk Üniversitesi İletişim Faküultesi Akademik Dergisi, 5(4), 5-17.

Jelassi, T. ve Enders, A. (2004). Leveraging Wireless Technology for Mobile Advertising. European Conference on Information Systems (ECIS) (s. 1-12). AIS Electronic Library.

Karaçizmeli Güzeler, A. (2010). Mobil Pazarlama Ve Sms (Kısa Mesaj) İle Yapılan Reklam Ve Kampanyalarn Tüketici Davranısı Üzerindeki Etkilerine Yönelik Bir Uygulama: Şanlurfa Örneği. (Yüksek Lisans Tezi). Harran Üniversitesi Sosyal Bilimler Enstitüsü, Şanlıurfa.

Kavassalis, P., Spyropoulou, N., Drossos, D., Mitrokostas, E., Gikas, G. ve Hatzistamatiou, A. (2003). Mobile Permission Marketing: Framing the Market Inquiry. International Journal of Electronic Commerce, 8, 55-79. doi: 10.1080/10864415.2003.11044286

Krejcie, R. V. ve Morgan, D. W. (1970). Determining Sample Size For Research Activities. Educationaland Psychological Measurement, 30, 607-610. doi: 10.1177/001316447003000308

Mobile Marketing Association. (2009, Kasim 17). Mobile Marketing Association Web Sitesi: https://www.mmaglobal.com/news/mma-updates-definition-mobile-marketing, 05.02.2019

Nakip, M. (2003). Pazarlama Arastırmalar Teknikler ve (SPSS Destekli) Uygulamalar. Ankara: Seçkin Yayınc1lı.

Peters, C., Amato, C. H. ve Hollenbeck, C. R. (2007). An Exploratory Investigation of Consumers' Perceptions of Wireless Advertising. Journal of Advertising, 36, 129-145. doi: 10.2753/JOA0091-3367360410

Phau, L. ve Teah, M. (2009). Young Consumers' Motives For Using SMS and Perceptions Towards Sms Advertising. Direct Marketing: An International Journal. 3, 97-108. doi: 10.1108/17505930910964768

Rettie, R. ve Brum, M. (2001). M-commerce: the Role of SMS Text Messages. Conference on Telecommunications and Information Markets. Karlsruhe, Germany.

Scharl, A., Dickinger, A. ve Murphy, J. (2005). Diffusion And Success Factors of Mobile Marketing. Electronic Commerce Research and Applications, 4, 159-173. doi: 10.1016/j.elerap.2004.10.006

Shankar, V. ve Balasubramanian, S. (2009). Mobile Marketing: A Synthesis And Prognosis. Journal of Interactive Marketing, 23, 118-129. doi: 10.1016/j.intmar.2009.02.002

Ström, R., Vendel, M. ve Bredican, J. (2014). Mobile Marketing: A Literature Review on İts Value for Consumers. Journal of Retailing and Consumer Services, 21, 1001-1012. doi: 10.1016/j.jretconser.2013.12.003

Sultan, F., Rohm, A. J. ve Gao, T. (2009). Factors Influencing Consumer Acceptance of Mobile Marketing: A TwoCountry Study of Youth Markets. Journal of Interactive Marketing, 23, 308-320. doi: 10.1016/j.intmar.2009.07.003

Tekkanat, E. ve Topaloğlu, M. (2016). The Study of Customer Attitudes towards SMS Advertisements. 3rd Global Conference on Business, Economics, Management And Tourism (s. 32-38). Rome: Procedia Economics and Finance. doi: $10.5539 /$ ijms.v4n1p77

Tsang, M. M., Ho, S. C. ve Liang, T. P. (2004). Consumer Attitudes Toward Mobile Advertising: An Empirical Study. International Journal of Electronic Commerce, 8, 65-78. doi: 10.1080/10864415.2004.11044301

Usta, R. (2009). Üniversite Öğrencilerinin Mobil Reklamcıllğa Karşı Tutumları, Doğuş Üniversitesi Dergisi, 10 (2), 294 309

Ural, A. ve Kılıç, İ. (2005). Bilimsel Araștırma Süreci ve SPSS ile Veri Analizi. Ankara: Detay Yayınları.

Xu, H., Teo, H. H. ve Wang, H. (2003). Foundations of SMS Commerce Success: Lessons from SMS Messaging And Co-Opetition. Proceedings of the 36th Hawaii International Conference on System Sciences (s. 1-10). Big Island, HI, USA, USA: IEEE Xplore.

Van der Waldt, D., Rebello, T. M. ve Brown, W. J. (2009). Attitudes of Young Consumers Towards SMS Advertising. African Journal of Business Management, 3, 444-452.

Varnali, K. ve Toker, A. (2010). Mobile Marketing Research: The State of the Art. International Journal of Information Management, 30, 144-151. doi: 10.1016/j.ijinfomgt.2009.08.009

Zhang, J. ve Mao, E. (2008). Understanding The Acceptance of Mobile SMS Advertising Among Young Chinese Consumers. Psychology \& Marketing, 25, 787-805. doi:10.1002/mar.20239

\section{EXTENDED ABSTRACT}

The widespread use of mobile phones and developments in mobile technology have enabled brands to benefit from a new medium in their marketing activities. Personal mobile phones have increased the frequency and speed of communication. In this context, developments in mobile communication technology in particular have brought about innovations in the way brands communicate with their consumers. Thus, mobile communication has reached a position that exceeds the traditional communication purpose and supports marketing communication. This new medium, which is rapidly integrated into the marketing communication process, has started to help brands measure the impact of their advertisements and reach consumers in a more cost-effective manner. In this study, which was prepared to understand the trends of the young consumer mass for SMS advertisements, which is the first and most widely used application of mobile marketing, many foreign and domestic studies were utilized. 
In this context, firstly, after an in-depth literature review, quantitative analyzes were performed. Significant findings were obtained as a result of the research.

The findings of the research were compared with the previous studies and evaluations were made on their own. As a result of these developments, SMS advertisements are preferred by brands in order to convince consumers. In this context, in this study, it is aimed to clarify whether the tendency of university students towards SMS advertisements, which is one of the mobile marketing applications, is positive or negative. In line with the above, the general purpose of the research is to determine the direction (positive / negative) of the university students' tendency towards mobile advertisements made by short message (SMS) method which is the first and most widely used application of mobile marketing. In this context, the students who study in the departments of Journalism, Public Relations and Publicity, Radio Television and Cinema, and Advertising within Ege University Faculty of Communication have formed the research universe. A questionnaire study was applied to 395 students who were included in the research universe. Descriptive and correlational research model was used in accordance with the aim of the study. In this context, in line with the data obtained from the survey, the general trend towards SMS advertisements sent to students by brands was found to be positive. Referring to Turkey is special in previous studies on this issue in more general research has found that focused on mobile marketing and general consumer audience. SMS advertisements, the first application of mobile marketing, and the study of university students have not been found in the literature. When the results of the sample studies in this context are examined, it is observed that the general tendency towards SMS advertisements is negative. According to the data obtained within the scope of the research, the sectors in which SMS advertisements are the most common are; telecommunications, finance and cosmetics. When the assessment is made in the context of gender variable, SMS is mostly received from cosmetic sector for women and SMS is mostly received from telecommunication sector for men. In this context, it can be said that the brands that send advertising messages to consumers have correctly segmented their target audience. Because, it is seen that women respond to the question whichever sector you want to receive the most messages in the survey. As with all other advertising campaigns, reaching the right audience with appropriate content will increase the impact. At this point, mobile channels provide great convenience to brands. Since mobile devices are completely personal, all demographic information such as gender, age, educational status, etc. can be accessed directly and easily.

In this context, SMSs with advertising content can be delivered to the appropriate target group instantly and at low cost. As a result of this research, SMS advertisements are considered important in mindfulness, which is a preliminary preparation that leads participants to the purchase decision. However, when making the purchase decision, participants stated that they were not affected by SMS ads only. Messages sent without the consent of the consumer cause negative attitudes towards the consumer towards SMS advertising. As a result, the overall trend towards SMS advertisements delivered to consumers was found to be positive. Particularly, the general thoughts of the participants are positive in terms of the fact that the messages received can be remembered and the retention of the product and service. In addition, this positive trend increases further if the incoming messages are received with the consent of the participants. However, advertising campaigns on mobile phones are very sensitive and brands that prefer this type of advertising should be careful not to disturb the users. As a result, according to the research findings, the majority of the participants stated that the allowed SMS advertisements did not bother them. However, they stated that the messages coming out of their permission disturbed them and they did not react to them even though they knew their legal rights. The important point is that unauthorized messages disturb consumers and there is a possibility of creating a negative image in their minds towards the brand. For this reason, it is very important to obtain the permissions of the people who will send advertising messages in all SMS based advertising campaigns. 